JECED : Journal of Early Childhood Education and Development

Homepage : http://jurnalftk.uinsby.ac.id/index.php/JCED

P-ISSN : 2715-8454; E-ISSN : 2715-8446 JECED, Vol. 3, No. 1, Juni 2021 (33-40) Email : jeced@uinsby.ac.id

\title{
Strategi Pendidikan dalam Menumbuhkan Kemampuan Berfikir Kritis Anak Usia Dini di Masa Covid-19
}

\author{
Imam Syafi' i ${ }^{1}$, Azimatul Chusnah ${ }^{2}$, Nur Alvi Inayati ${ }^{3}$, Linda Puspita Sari ${ }^{4}$ \\ 1, 2, 3,4 UIN Sunan Ampel Surabaya, Surabaya, Indonesia
}

\begin{abstract}
This study aims to describe and understand the strategy of educators in carrying out their duties during the COVID-19 pandemic in fostering critical thinking skills in early childhood. This research method uses qualitative research with a case study approach. Data collection techniques in this study using observation, interviews, and documentation. While the data analysis used the Miles and Huberman model with the stages of data reduction, data presentation, verification, and conclusion drawing. The results of this study indicate that, first, there is a change in the strategy for implementing the duties of teachers/educators, namely as planners and assessors of children's learning outcomes. While the task as implementers in early childhood educator learning in collaboration with teachers / educators at home, namely the child's parents. Second, the strategy of teachers/educators at home to cultivate children's critical thinking skills is to invite children to understand the reasons for schooling at home, the reasons for the obligation to use masks when leaving the house and others by using discussion and exemplary methods.
\end{abstract}

DOI : https://doi.org/10.15642/jeced.v3i1.816

\section{Article Info}

Article history:

Received: October 20, 2020

Approved: June 30, 2021

Published online: June 30, 2021

\section{Keywords:}

education strategy,

critical thinking skills,

early childhood,

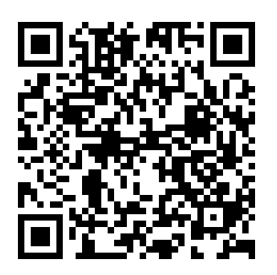

Informasi Artikel

Riwayat Artikel

Diterima: 20102020

Disetujui: 30062021

Publikasi online: 30062021

\section{Kata kunci:}

strategi pendidikan,

kemempaun berfikir kritis,

anak usia dini, tahapan yakni reduksi data, penyajian data, verifikasi, dan pengambilan kesimpulan. Hasil penelitian ini menunjukkan bahwa, pertama terdapat perubahan dalam strategi pelaksanaan tugas guru/pendidik yakni sebagai perencana dan penilai hasil pembelajaran anak. Sedangkan tugas sebagai pelaksana dalam pembelajaran pendidik anak usia dini bekerjasama dengan guru/pendidik di rumah yakni orang tua anak. Kedua, strategi guru/pendidik di rumah untuk menumbuhkan kemampuan berfikir kritis anak yakni mengajak anak untuk memahami alasan bersekolah di rumah, alasan kewajiban menggunakan masker saat keluar rumah dan lainnya dengan menggunakan metode diskusi dan keteladanan. 


\section{PENDAHULUAN}

Covid-19 (Corona Virus disease) kini telah menyebar ke sejumlah negara. Covid-19 merupakan penyakit menular yang disebabkan oleh sindrome pernapasan akut coronavirus 2 (severe acute respiratory syndrome coronavirus 2 atau SARS-CoV-2), Penyakit ini ditularkan melalui droplet (percikan) pada saat berbicara, batuk, dan bersin dari orang yang terinveksi virus corona. Yulrianto dan ahmad menyatakan gelaja manusia yang terpapar COVID-19 yaitu saluran pernapasan terganggu, suhu tubuh panas tinggi, batuk. Tanda-tanda munculnya gejala sekitar 514 hari (Dewi, 2020, p.1). Selain itu, penyakit ini dapat menular melalaui kontak fisik (sentuhan atau jabat tangan) dengan penderita serta menyentuh wajah mulut, dan hidung oleh tangan yang terpapar virus corona. Virus ini dapat menyerang manusia maupun hewan. Ketika menyerang manusia Coronavirus menyebabkan infeksi saluran pernafasan seperti flu, MERS (Middle East Respiratory Syndrome) dan SARS (Svere Acute Repiratory Syndrome) (Setiawan, 2020).

Penyebaran virus tersebut sangat cepat dan sampai sekarang vaksin masih belum ditemukan. Maka dari itu, pemerintah melakukan tindakan pencegahan agar virus tidak menyebar semakin luas yakni dengan menjaga jarak fisik (Phisical Distancing) dan jaga jarak (Sosial Distancing). Dengan adanya pandemi ini mengakibatkan dampak perubahan pada seluruh dunia yakni perubahan dari segi bidang ekonomi, bidang pendidikan, kesehatan dan sosial budaya

Dampak pandemi ini sangat berpengaruh pada dunia pendidikan di Indonesia. Untuk mencegah penyebaran virius Covid-19, Menteri Pendidikan dan Kebudayaan (Mendikbud) menerbitkan aturan baru yang tertera dalam Surat Edaran Nomor 4 tahun 2020 tentang pelaksanaan pendidikan masa Darurat Coronavirus Diseasae. Adapun pembelajaran dan tugas yang diberikan pada siswa harus disesuaikan dengan kondisi masing-masing yang tidak memberatkan anak serta orang tuanya termasuk akses yang digunakan dalam pembelajaran saat dirumah (Mendikbud, 2020). Pembelajaran jarak jauh ini diberlakukan mulai dari jenjang PAUD SD, SMP dan SMA sampai perguruan tinggi. Kebijakan yang dibuat pemerintah tersebut berlaku pada tingkat pusat hingga daerah.

Sebelum adanya pandemi, pembelajaran disekolah dilakukan tatap muka, semua guru selalu mendidik anak-anak dengan baik seperti memberi stimulus agar anak mencapai perkembangan sesuai usianya, mendidik ilmu agama dan lain sebagainya. Akan tetapi, dengan adanya virus covid-19 ini pembelajaran yang ditujukan pada anak usia dini ini berubah menjadi pembelajaran jarak jauh. Hal ini tentunya akan mempengaruhi proses tumbuh kembang anak.

Dengan adanya kendala saat belajar di masa pandemi ini, dapat mengakibatkan tidak optimalnya proses tumbuh kembanga anak. Sebagai pendidik, guru PAUD berperan penting untuk mengembangkan potensi awal anak, memenuhi tumbuh kembang anak dan membuat anak siap saat memasuki jenjang sekolah dasar. Sesuai dengan UUSPN N0. 20 tahun 2003 pasal 1 ayat 14 menjelaskan tentang pendidikan anak usia dini (PAUD) adalah suatu strategi pembinaan yang diberikan kepada anak-anak mulai sejak lahir sampai usia enam tahun yang dilakukan melalui pemberian rangsangan pendidikan untuk membantu tumbuh kembang anak maupun rohani agar anak memiliki kesiapan saat memasuki jenjang sekolah dasar (Sistem Pendidikan Nasional, 2003).

Pendidikan untuk anak usia dini sangat penting sebelum masuk sekolah dasar. Melalui didikan yang diberikan guru dengan menggunakan metode dan kurikulum yang benar anak dapat bermain dan menyalurkan energinya melalaui kegiatan yang bermacam-macam. Kegiatan tersebut seperti kegiatan fisik, keterampilan tangan, musik, mengajarkan anak cara berinteraksi yang benar, mengenalkan huruf, mengasah anak agar berfikir kritis, membimbing anak agar bisa membaca dan mengasah kognitif anak serta lain sebagainya. Namun sesuai dengan aturan Permendikbud, pemberian stimulasi perkembangan untuk perkembangan kognitif, bahasa, fisik motorik, sosial emosional, agama dan moral serta seni harus dilakukan di rumah masing-masing peserta didik.

Sujiono menyatakan mendidik anak usia dini meliputi segala hal yakni memberikan stimulus pada anak, bimbingan, perawatan, dan pengasuhan pada anak usia dini. Hal tersebut memberi dampak positif yakni terwujudnya lingkungan yang dapat mengeksplor pengalaman anak. Selain itu juga anak dapat memperoleh pengetahuan dari lingkungan tersebut melalui 
berbagai cara yakni mengamati, bereksperimen, meniru yang dilakukan anak secara berulangulang dan melibatkan semua potensi yang dimiliki anak (Sujiono \& Nurani, 2013, p.93).

Agustin mengatakan, saat mendidik anak usia dini harus memerlukan kedekatan dan komunikasi yang intens baik verbal maupun non verbal (Agustin \& Puspita, 2020). Anak usia dini juga memerlukan permainan yang dilakukan secara tatap muka. Hurlock mengatakan bahwa pada masa anak-anak dikenal dengan sebuah tahapan bermain karena rutinitas yang dilakukan anak-anak menggunakan mainan (Elizabet, 1991, p.70). Vygotsky juga mengatakan bahwa permainan merupakan kegiatan yang dapat menstimulus anak untuk mengenal aturan masyarakat dan mengenal moral bagaimana cara mengatasi berbagai macam masalah yang terjadi dalam kehidupan. Hal ini sesuai dengan kompetensi sosial yang menunjukan kemampuan anak untuk mengendalikan emosi diri dan menjalin hubungan baik dengan orang lain (Muchtar \& Razak, 2018).

Moeslichatun mengungkapkan bermain juga memiliki peran penting bagi perkembangan kognitif dan sosial anak serta dapat meningkatkan perkembangan bahasa, moral, kreativitas dan perkembangan fisik anak (Pratiwi, 2017, p.5). Docket dan Flleer mengungkapkan bahwa bermain merupakan kebutuhan bagi anak yang bermanfaat dalam mengembangkan kemampuan dirinya. Juga pendapat susanto yakni dengan bermain dapat membentuk sikap mental dan kepribadian anak diantaranya anak dapat menyelesaikan masalah dalam kesulitan terendah sampai yang tertinggi, melatih sikap sabar anak saat menggu giliran bermain, anak dapat berfikir kritis dengan cara yang baik untuk memenangkan permainan tersebut dan melatih anak saat mengadapi kekalahan (Pratiwi, 2017). Tatminingsih menyatakan bahwa model pembelajaran berbasis permainan komprehensif dapat meningkatkan kemampuan kognitif anak. Model permainan tersebut dapat diterapkan pada model sentra maupun kelompok (Tatminingsih, 2019, p.2).

Strategi utama pendidikan anak usia dini di lembaga pendidikan untuk seluruh aktivitas pembelajarana anak usia dini adalah bermain. Sebuah kegiatan bermain dirancang oleh guru AUD sebaik mungkin untuk mencapai tujuan pembelajaran dan memfokuskan pada salah satu aspek perkembangan yang sangat cocok untuk menstimulus perkembangana anak. Berdasarkan pendapat dari para ahli maka para guru PAUD Ketika menerapkan pembelajaran dengan bermain harus disesuaikan dengan perencanaan dan penggunaan media yang sesuai dengan usia anak dan sesuai dengan proses pembelajaran sehingga dapat menstimulus anak dan memaksimalkan perkembangan. Dengan pembelajaran daring ini maka guru paud harus menyediakan media yang mudah didapatkan anak dan yang mudah dikerjakan anak agar tidak mempersulit orang tua dan anak didik.

Dalam peraturan Menteri Pendidikan dan Kebudayaan nomor 137 tentang standar nasional pendidikann yakni sebagai tenaga profesional pendidik anak usia dini memiliki tugas yang penting untuk membuat pembelajaran, menilai, membimbing dari mulai awal sampai anak bisa melakukannya, melatih mengasuh dan melindungi. Dengan menerapkan pemberlajaran daring maka Guru PAUD hanya memberikan pembelajaran melalaui video, zoom dan cara lainnya secara daring. Sehingga, tugas guru teralihkan pada orang tua yang ada dirumah ketika menuggu anak mengerjakan.

Dalam pembelajaran daring, Anak usia dini tidaklah dapat melaksanakannya secara mandiri, mereka membutuhkan keterlibatan orang tua sebagai pendamping mereka untuk ikut serta dalam pembelajaran jarak jauh tersebut. Jadi guru dan orang tua harus saling berkolaborasi untuk menstimulus anak usia dini agar aspek perkembangan kognitif, fisik motorik, sosial emosional, seni, agama dan bahasa dapat berkembang secara baik. Pentingnya aspek perkembangan anak usia dini sesuai dengan Peraturan Menteri pendidikan dan kebudayaan nomor 137(Permendibud 137, 2014).

Perkembangan kognitif merupakan salah satu aspek perkembangan individu yang meliputi kemampuan bentuk berpikir, pemecahan masalah dan adaptasi. Dalam perkembangan kognitif anak terdapat berbagai macam tingkatan yakni tahap sesnsorik motorik, tahap praoperasional, tahap operasional kongkret dan tahap operasional formal (Mu'min, 2013, p.3). Untuk aspek perkembangan bahasa memiliki tiga lingkup aspek perkembangan yakni pertama, memahami 
bahasa kedua, mengungkapkan bahasa dan ketiga, keaksaraan (Permendibud 137, 2014). Salah satu bagian perkembangan kogntif adalah anak dapat berfikir kritis.

Penelitian ini memfokuskan kajian pada perkembangan kognitif anak usia dini yaitu lingkup berfikir kritis berupa kemampuan dalam mengambil keputusan yang benar tentang apa yang harus dilakukan dan yang diyakini. Pengembangan kemampuan anak usia dini dalam berfikir kritis dapat menggunakan materi dan metode yang sesuai dengan tahapan kemampuan berfikir anak yang bersifat konkrit. Metode tanya jawab memegang peranan penting dalam mengembangkan kemampuan berpikir kritis anak. Menurut Stanley Hall dengan kegiatan bertanya guru dapat menimbulkan rasa ingin tahu anak didik, merangsang otak untuk berpikir kritis, memfokuskan perhatian anak didik serta mendiagnosis kesulitan belajar anak (Prasetyaningarum \& Rohita, 2015, p.). Yunita, Meilanie dan Fahrurrozi mengemukakan bahwa kemampuan berfikir kritis anak dapat ditingkatkan melalui pendekatan saintifik (Yunita \& Meilanie, 2019). Berdasarkan temuan-temuan peneliti terdahulu dijelaskan bahwa perkembangan kognitif dapat dipahami melalui kegiatan bermain dengan belajar yang berupa tanya jawab dan pendekatan siantifik dalam berbagai lingkup. Berdasarkan uraian tersebut diatas maka peneliti tertarik untuk melakukan penelitian yang berjudul "Strategi Pendidik Dalam Menumbuhkan Kemampuan Berfikir Kritis Anak Usia Dini Dimasa Covid-19”.

\section{METODE}

Dalam penelitian ini, Peneliti menggunakan pendekatan kualitatif dan metode studi kasus. Sukmadinata menyatakan penelitian kualitatif adalah prosedur penelitian yang menghasilkan data deskriptif berupa data-data tertulis atau lisan dari orang-orang dan dari perilaku yang diamati oleh peneliti secara utuh (Kemendikbud, 2018). Menurut Sukmadinata Studi kasus merupakan suatu penelitian yang dilakukan terhadap satu kesatuan sistem baik berupa program, kegiatan, peristiwa atau sekelmpok individu yang terkait oleh tempat, waktu atau ikatan tertentu (Fitrah \& Luthfiyah, 2018, p.208). Creswell mengatakan bahwa studi kasus adalah strategi kualitatif dimana peneliti mengkaji sebuah kejadian, sehingga peneliti harus mengumpulkan informasi yang lengkap dengan menggunakan beragam cara pengumpulan data selama waktu tertentu (Fitrah \& Luthfiyah, 2018). Penggunaaan metode ini digunakan untuk memperoleh pemahaman tentang strategi pendidik anak usia dini di masa covid-19 dalam menumbuhkan dan mengembangkan kemampuan berfikir kritis. Berdasarkan hasil, penelitian dideskripsikan dengan bahasa yang tepat dan sesuai fakta dilapangan yang ada saat penelitian.

Teknik pengumpulan data melalui observasi/pengamatan yang di dalamnya peneliti langsung turun ke lapangan untuk mengamati perilaku dan aktivitas individu di lokasi penelitian (Khoiruzzadi et al., 2020). Akan tetapi, dimasa pandemi covid-19 penelti hanya bisa mengobservasi perkembangan anak secara daring melalui bukti cara guru saat menstimulus anak agar dapat berfkir kritis. Bukti tersebut seperti foto, video dan lain sebagainya yang dikirimkan oleh orang tua. Dalam pengamatan ini, peneliti merekam dan mencatat dengan baik cara terstruktur maupun semi struktur (misalnya memantau perkembangan berfikir anak dari awal penelitian hingga akhir penelitian) aktivitas-aktivitas dalam lokasi penelitian. Selain observasi, pengumpulan data juga dilakukan melalui wawancara. Menurut Jhon Creswell dalam wawancara kualitatif, peneliti dapat melakukan wawancara berhadap-hadapan dengan partisipan, Saat melakukan wawancara bisa menggunakan dengan telepon atau terlibat dalam focus group interview yang terdiri dari enam sampai delapan orang per kelompok (Raco, 2018).

Teknik analisis data menggunakan teknik triangulasi. Analisi tersebut digunakan peneliti untuk memeperoleh hasil penelitian yang akurat. Triangulasi yaitu teknik pengumpulan data dari hasil yang diperoleh setelah observasi dengan memadukan data A dan data B. Proses analisis data selama di lapangan menggunakan model Miles dan Huberman yaitu : Pengumpulan data, reduksi data, penyajian data, serta pengambilan keputusan dan verifikasi (Wijaya, 2020):

\section{HASIL DAN PEMBAHASAN}

Stimulasi diberbagai aspek perkembangan anak usia dini salah satunya yakni perkembangan kognitif dilakukan oleh pendidik diseluruh lembaga PAUD di Indonesia. RA 
Muslimat NU 10 Banin Banat Gresik merupakan lembaga pendidikan bagi anak usia dini yang memberi pelayanan untuk anak empat hingga enam tahun secara sistematis dan intens. Pemberian stimulasi terhadap aspek perkembangan anak usia dini sesuai dengan aspek-aspek yang ditentukan dalam Standar Nasional Pendidikan bagi anak usia dini seperti aspek kognitif, bahasa, moral, seni, fisik motorik dan sosial emosional.

Pemberian stimulasi terhadap perkembangan kognitif anak usia dini di RA Muslimat NU 10 Banin Banat Gresik dilaksanakan berdasarkan indikator capaian perkembangan anak dalam Permendikbud No 137 Tahun 2014 tentang standar nasional pendidikan bagi anak usia dini. Aspek perkembangan kognitif dalam standar tersebut yakni seperti berfikir kritis, berpikir simbolik, belajar dan pemecahan masalah dengan indikator capaian perkembangan yang berbedabeda. Berikut indikator aspek perkembangan kognitif anak beserta lingkup perkembangannya sesuai Permendikbud No 137 Tahun 2014 antara lain :

Tabel 1. Indikator Capaian Perkembangan Kognitif

\begin{tabular}{|c|c|}
\hline Lingkup Perkembangan & Capaian Perkembangan Anak Usia 5-6 Tahun \\
\hline \multirow[t]{5}{*}{ Berpikir Simbolik } & 1. Menyebutkan bilangan $1-10$ \\
\hline & 2. Menggunakan bilangan untuk menghitung \\
\hline & 3. Mencocokkan bilangan dengan lambing bilangan \\
\hline & 4. Mengenal macam-macam huruf vokal dan konsonan \\
\hline & $\begin{array}{l}\text { 5. Merepresentasikan macam-macam benda dalam gambar } \\
\text { maupun tulisan }\end{array}$ \\
\hline \multirow[t]{8}{*}{ Berpikir Kritis } & 1. Mengenal perbedaan berdasarkan ukuran \\
\hline & 2. Menunjukkan inisiatif memilih tema dalam permainan \\
\hline & 3. Menyusun rencana kegiatan yang akan dilakukan \\
\hline & 4. Mengenal sebab-akibat lingkungannya \\
\hline & $\begin{array}{l}\text { 5. Mengelompokkan benda berdasarkan warna, bentuk dan } \\
\text { ukuran }\end{array}$ \\
\hline & 6. Mengelompokkan benda yang lebih banyak kedalam \\
\hline & $\begin{array}{l}\text { kelompok yang sejenis atau lebih dari } 2 \text { variasi } \\
\text { Mengenal pola } A B C D-A B C D\end{array}$ \\
\hline & 8. Megurutkan benda berdasarkan ukuran terkecil keterbesar \\
\hline Belajar dan Pemecahan & 1. Menunjukkan aktivitas yang eksploratif dan menyelidikk \\
\hline \multirow[t]{4}{*}{ Masalah } & 2. Memecahkan masalah sederhana dalam kehidupan sehari- \\
\hline & 3. Menerapkan pengetahuan atau pengalaman dalam konteks \\
\hline & baru \\
\hline & 4. Menunjukkan sikap kreatif dalam menyelesaikan masalah \\
\hline
\end{tabular}

Berdasarkan lingkup dan capaian perkembangan kognitif yang telah diuraikan maka peneliti menentukan lingkup perkembangan berfikir kritis sebagai fokus untuk penelitian. Hal tersebut terfokus saat anak telah melalui pembelajaran di rumah serta orang tua anak sebagai pendidik di rumah telah memberikan layanan dan stimulasi bagi anak meskipun tidak semua orang tua dapat memberikannya. Irma, Nisa dan Sururiyah mengungkapkan bahwa keterlibatan orang tua atas didikan yang diberikan kepada anak dalam pendidikan dipengaruhi oleh beberapa hal seperti status sosial, wujud keluarga, tahap perkembangan dalam keluarga dan model peran.

Adanya pandemi covid-19 menjadi sebab pemberian stimulasi perkembangan di RA Muslimat NU 10 Banin Banat Gresik mengalami perubahan yang semula berpusat pada guru dan anak melalui kegiatan belajar dengan bermain menjadi menjadi berpindah kepada orang tua anak. Hal tersebut sesuai dengan kebijakan surat edaran yang dikeluarkan oleh Kementrrian Pendidikan dan Kebudayaan (Kemendikbud) No 4 Tahun 2020 tentang pelaksanaan pendidikan di masa darurat penyebaran covid-19. Kebijakan tersebut mengakibatkan berubahnya pelaksanaan pembelajaran diberbagai jenjang pendidikan mulai dari pendidikan anak usia dini hingga 
pendidikan tinggi. Perubahan pelaksanaan pendidikan memberi dampak terhadap strategi pendidik dalam pembelajaran kepada anak.

Kegiatan pembelajaran yang dilakukan oleh orang tua anak di rumah menjadi hal yang menarik dan menantang. Pelaksanaan pembelajaran tersebut memberikan peran kepada orang tua sebagai pendidik yang tidak hanya terfokus pada capaian kurikulum kenaikan kelas maupun kenaikan akhir namun juga pembelajaran yang bermakna dan memberikan pengalaman bagi anak. Pokok materi yang diwajibkan pada anak sesuai dengan Standar Kompetensi (SK) dan Kompetensi Dasar (KD) disesuaikan dengan arah pendidikan serta kondisi yang ada seperti penyebaran virus covid-19 keberbagai negara. Hal tersebut berarti bahwa pendidikan tetap bersifat fleksibel atau tidak kaku yang harus terfokus pada kurikulum dan silabus namun lebih kepada kondisi dan minat anak. Tidak hanya itu, fasilitias belajar bagi anak juga lebih diperhatikan. Begitupun dengan hasil karya pembelajaran yang sebelumnya bersifat kuantitatif dan berfokus pada keterampilan, pengetahuan dan sikap dengan pemberian nilai berupa angka menjadi kualitatif yang memudahkan guru dalam menilai tanpa membingungkan angka.

Seluruh hal yang terkait dalam kebijakan pelaksanaan pendidikan dimasa covid-19 sudah sesuai dengan prinsip-prinsip pembelajaran di PAUD tepatnya pada tema dan materi yang mencakup prinsip keinsidentalan, kedekatan, kesederhanaan dan juga kemenarikan. Dalam masa pandemi, guru sebagai pendidik di sekolah dan orang tua sebagai pendidik di rumah harus bekerjasama dalam memberikan stimulasi perkembangan bagi anak. Hal tersebut berarti bahwa panggilan pendidik tidak hanya diperuntukkan bagi seorang guru namun juga kepada orang tua sebagai pendidik khusunya pendidik pertama bagi anak usia dini. Wahy mengungkapkan bahwa keluarga merupakan dasar pendidikan pertama dan yang utama bagi anak sebelum pendidikan formal. Untuk mencapai tujuan yang diharapkan maka kerjasama tersebut dapat diwujudkan dengan pembagian peran antara guru dan orang tua. Guru sebagai pendidik anak di sekolah berperan dalam merencanakan dan menilai hasil pembelajaran. Sedangkan orang tua sebagai pendidik anak di rumah berperan dalam melaksanakan pembelajaran yang diberikan oleh guru.

Kerjasama antara guru dan orang tua juga terjadi di RA Muslimat NU 10 Banin Banat Gresik. Kerjasama dalam pembelajaran dimasa pandemi tersebut yakni Guru memfasilitasi alat dan bahan belajar bagi anak disetiap minggunya dengan tujuan agar tidak memberatkan orang tua yang kemudian orang tua harus mengambil ke sekolah secara bergiliran dan tetap dengan mematuhi protol kesehatan. Kemudian ditiap pagi dihari efektif pembelajaran, guru mengirimkan video pembelajaran digrup whatsapp kelompok kelas sebagai pengganti pembelajaran di sekolah. Setelah itu, anak-anak mengerjakan sesuai panduan didalam video dan hasilnya dikirim melalui grup berupa foto, video maupun pesan suara.

Hasil karya anak maupun dokumentasi yang dikirim oleh orang tua selanjutnya dilakukan analisis dan penilaian. Penilaian tersebut terdiri dari Belum Berkembang (BB), Mulai Berkembang (MB) dan Berkembang Sangat Baik (BSB) yang diseuaikan dengan indikator penilaian yang telah dicapai. Kemudian hasil penilaian yang ada dikomunikasikan bersama orang tua secara pribadi untuk tindak lanjut ataupun perbaikan jika diperlukan. Berikut dokumentasi hasil pembelajaran yang dikirimkan oleh orang tua anak :
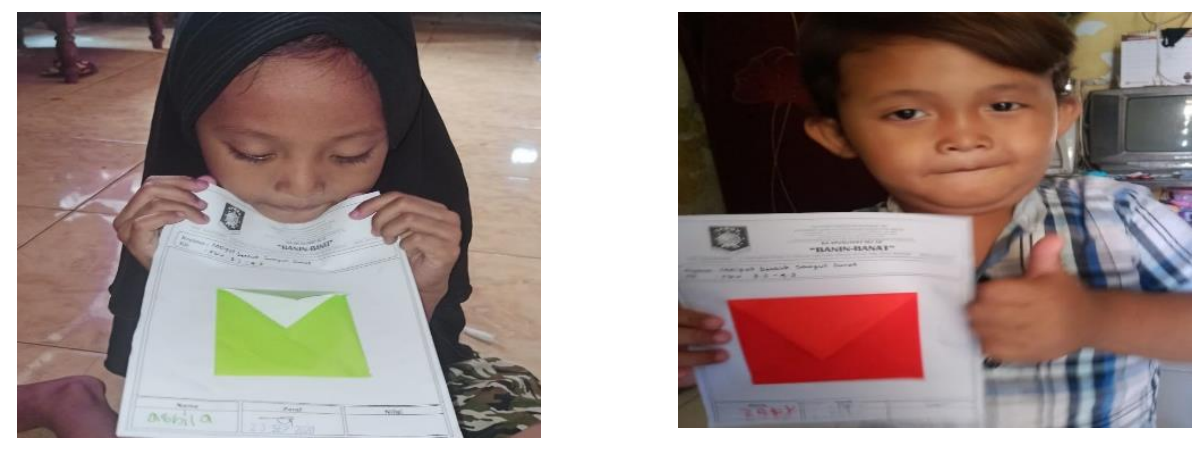

Gambar 1. Dokumentasi Hasil Pembelajaran 
Dokumentasi hasil pembelajaran tersebut membuktikan bahwa anak mampu menyelesaikan kegiatan belajar dengan bermain sesuai arahan orang tua. Dokumentasi tersebut menunjukkan bahwa kemampuan kognitif dalam konsep penugasan masuk dalam kategori Mulai Berkembang (MB). Hal tersebut dibuktikan dengan gambar 1 dan gambar 2 yang memperlihatkan bahwa anak sudah mulai berkembang dan berpikir bagaimana cara membentuk dan melipat sampul surat yang baik tanpa membeli dan keluar dari rumah sebagai salah satu upaya pencegahan dari penularan virus covid-19. Dan hal tersebut sudah sesuai dengan lingkup berpikir kritis yakni mengenal sebab-akibat lingkungannya. Tidak hanya itu, hal tersebut juga sudah sesuai dengan implementasi kurikulum 2013 dan harapan pemerintah mengenai pembelajaran HOTS atau Higher Order Thinking yang berarti kemampuan dalam berpikir kritis (Kemendikbud, 2018).

Strategi orang tua sebagai pendidik di rumah dalam pemberian stimulasi perkembangan bagi anak yakni menggunakan strategi diskusi atau percakapan dan keteladanan. Strategi diskusi tersebut seperti mengkomunikasikan tema ataupun pembahasan bersama anak seperti mengapa belajar dilakukan dirumah, mengapa jika keluar dari rumah harus memakai masker dan lainnya yang terkait dengan tema pembelajaran pada saat itu. Dengan mengajak anak berdiskusi, terciptalah interaksi dan suasana yang menyenangkan antara pendidik dan anak sehingga konsep yang disampaikan dapat dipahami anak. Selain itu, strategi keteladanan juga diterapkan sebagai contoh bagi anak sebelum melakukan seperti mencontohkan bacaan do'a sebelum belajar dan lainnya.

Segala materi yang berhubungan maupun yang dapat dihubungkan dengan covid-19 sebaiknya mulai diberikan pada anak usia dini agar anak dapat memahami kondisi saat ini. Materi tentang covid-19 dirasa cocok untuk menumbuhkan kemampuan kognitif anak usia dini khususnya dalam lingkup perkembangan berpikir kritis. Karena dari hal tersebut, anak akan dapat mengenal sebab akibat yang merupakan indikator capaian perkembangan yang diharapkan.

\section{SIMPULAN DAN SARAN}

Strategi pendidik anak usia dini dimasa covid-19 yakni terlibatnya orang tua sebagai pendidik di rumah yang turut berperan dan bekerjasama dalam memberikan stimulasi perkembangan anak. Hasil dari penelitian yang dilakukan yakni anak sudah mampu mencapai indikator capaian dalam berpikir kritis yakni mengenal sebab akibat lingkungannya. Penelitian ini juga dikategorikan berhasil karena dapat mencapai indikator perkembangan kognitif yang diharapkan yakni lingkup perkembangan berpikir kritis.

Berdasarkan pengalaman melaksanakan penelitian mengenai strategi pendidik anak usia dini dimasa covid-19 diatas, pada bagian ini peneliti mengharapkan kritik dan saran yang membangun dari pembaca sebagai perbaikan dalam penelitian yang akan datang.

\section{AKNOWLEDGMENT}

Peneleitian ini di dukung oleh sekolah RA Muslimat NU 10 Banin-Banat Gresik dan UIN Sunan Ampel Surabaya

\section{DAFTAR RUJUKAN}

Agustin, M., \& Puspita, R. D. (2020). Pengaruh Metode Karyawisata terhadap Keterampilan Berbicara pada Anaka Sekolah Dasar (SD). JCP: Jurnal Cakrawala Pendas, 6(1), 84-92.

Dewi, W. A. F. (2020). Dampak Covid-19 Terhadap Implementasi Pembelajaran Daring di Sekolah Dasar. Edukatif: Jurnal Ilmu Pendidikan, 2(1), 55-61.

Elizabet, H. (1991). Psikologi Perkembangan Suatu endekatan Sepanjajng Rentang Kehidupan (5td ed). Erlangga.

Fitrah, M., \& Luthfiyah. (2018). Metodologi Penelitian: Penelitian Kualitatif, Tindakan Kelas \& Studi Kasus. Jejak Publisher.

Permendibud 137, (2014).

Kemendikbud, dirjen G. (2018). Buku Pegangan Pembelajaran Berorientasi pada Keterampilan Berpikir Tingkat Tinggi. http://repositori.kemdikbud.go.id/11316/1/01._Buku_Pegangan_Pembelajaran_HOTS_20 
18-2.pdf

Sistem Pendidikan Nasional, Pub. L. No. Nomor 20 Tahun 2003 (2003).

Khoiruzzadi, M., Barokah, M., \& Kamila, A. (2020). Upaya Guru Dalam Memaksimalkan Perkembangan Kognitif, Sosial dan Motorik Anak Usia Dini. JECED : Journal of Early Childhood Education and Development, 2(1), 40-51. https://doi.org/10.15642/jeced.v2i1.561

Mu'min, S. A. (2013). Teori Perkembangan Kognitif Jean Piaget. Al-Ta'dib, 6(1), 89-99.

Muchtar, H. S., \& Razak, A. I. M. (2018). Bermain Sebagai Intervensi Untuk Menigkatkan Kompetensi Sosial Anak. Jurnal Pendidikan Anak Usia Dini, 12(November), 241-250.

Pelaksanaan Kebijakan Pendidikan dalam Masa Darurat Penyebaran Coronavirus Disease (Covid-19), Pub. L. No. 4 Tahun 2020 (2020). https://pusdiklat.kemdikbud.go.id/suratedaran-mendikbud-no-4-tahun-2020-tentang-pelaksanaan-kebijakan-pendidikan-dalammasa-darurat-penyebaran-corona-virus-disease-covid-1-9/

Prasetyaningarum, A., \& Rohita. (2015). Pengaruh Keterampilan Bertanya Guru Terhadap Kemampuan Berpikir Kritis Anak Kelompok B di TK Al-Hidayah. PAUD Teratai, 3(3), 1-6.

Pratiwi, W. (2017). Konsep bermain pada anak usia dini. Tadbir: Jurnal Manajemen Pendidikan Islam, 5(2).

Raco, J. (2018). Metode penelitian kualitatif: jenis, karakteristik dan keunggulannya. https://doi.org/10.31219/osf.io/mfzuj

Safaruddin, S., Ibrahim, N., Juhaeni, J., Harmilawati, H., \& Qadrianti, L. (2020). The Effect of Project-Based Learning Assisted by Electronic Media on Learning Motivation and Science Process Skills. Journal of Innovation in Educational and Cultural Research, 1(1), 22-29. doi:https://doi.org/10.46843/jiecr.v1i1.5

Setiawan, A. R. (2020). Lembar Kegaitan Literasi Saintifik untuk Pelajaran JArak Jauh Topik Penyakit Coronavirus 2019 (COVID-19). Edukatif: Jurnal Ilmu Pendidikan, 2(1), 28-36.

Sujiono, \& Nurani, Y. (2013). Konsep Dasar Pendidikan Anak Usia Dini. PT. Indeks.

Tatminingsih, S. (2019). Alternative Stimulasi Kemampuan Kognitif melalui Penerapan Model Pembelajaran Berbasis Permainan Komprehensif. Obsesi : Jurnal Pendidikan Anak Usia Dini, 3(1), 183-190. https://doi.org/10.31004/obsesi.v3i1.130

Wijaya, U. (2020). Analisis Data Kualitatif Teori Konsep dalam Penelitian Pendidikan. Sekolah Tinggi Theologia Jaffray.

Yunita, H., \& Meilanie, S. M. (2019). Meningkatkan Kemampuan Berpikir Kritis melalui Pendekatan Saintifik. Obsesi: Jurnal Pendidikan Anak Usia Dini, 3(2), 425-432. https://doi.org/10.31004/obsesi.v3i2.228

\section{AUTHOR}

Dr. Imam Syafi'i, S.Ag., M.Pd., M.Pd.I berasal dari surabaya dan sekarang masih aktif sebagai dosen di Universitas Islam Negeri Sunan Ampel Surabaya. Lahir di Kediri, 20 November 1970.

Azimatul Chusnah, S.Pd berasal dari Gresik dan sekarang masih aktif sebagai guru di RA Muslimat NU 10 Banin-banat Gresik. Lahir di Gresik, 24 Juli 1973

Nur Alvi Inayati berasal dari Gresik dan sekarang masih aktif sebagai mahasiswi di Universitas Islam Negeri Sunan Ampel Surabaya. Lahir di Gresik, 12 Januari 1999.

Linda Puspita Sari dari Gresik dan sekarang masih aktif sebagai mahasiswi di Universitas Islam Negeri Sunan Ampel Surabaya. Lahir di Gresik, 25 September 1999. 